\title{
Microstrip array antenna with inset-fed for WLAN application
}

\author{
Norfishah Ab Wahab, W. Nor Syafizan W. Muhamad, Zuhani Ismail Khan, Suzi Seroja Sarnin \\ Faculty of Electrical Engineering, Universiti Teknologi Mara (UiTM), Malaysia
}

\begin{tabular}{l}
\hline \hline Article Info \\
\hline Article history: \\
Received May 1, 2019 \\
Revised Jul 20, 2019 \\
Accepted Aug 7, 2019 \\
\hline
\end{tabular}

\section{Keywords:}

Array antenna

Inset-Fed

Microstrip

Patch antenna

\begin{abstract}
This paper proposed three designs of microstrip array patch antennas, to resonate at $2.4 \mathrm{GHz}$. The purpose of the study is to achieve size reduction with acceptable performance for wireless communication system applications. Based on the array concept, the array antennas are arranged using corporate network technique. It is found that the simulated $4 \times 3$ patch array antenna achieved the compact size with dimension reduced up to $26 \%$ compared to $4 \times 1$ and $4 \times 2$ array patch antennas. In terms of return loss, the antenna attenuated more than $19 \mathrm{~dB}$. The $4 \times 3$ patch array antenna is fabricated and measured using RO4350 microstrip substrate to validate the concept. The responses are found in good agreement between simulation and measurement.
\end{abstract}

Copyright () 2020 Institute of Advanced Engineering and Science. All rights reserved.

Corresponding Author:

Norfishah Ab Wahab,

Faculty of Electrical Engineering, 40450 Shah Alam, Selangor, Malaysia.

Email: fishahahu@ gmail.com

\section{INTRODUCTION}

An efficient and high performance antenna is very important in Wireless Communication Systems. This is due to the fact that the antenna performance is directly impact on the quality of wireless communications [1-6]. For the application of emerging technology, it requires compact in size components with low in power usage and robustness. Researched on various antenna topologies were reported. These topologies were experimented on different type of technology available today [7-12]. However, a low cost and efficient antenna with ease in manufacturing process is the main interest among the industry players. Microstrip technology is well known for its low cost, easy to materialize with acceptable antenna performance [13-16]. Based on these facts, microstrip substrate is chosen because of its low cost, compact in size with an acceptable performance level that is required by the wireless communication system [17-20]. However, there are limitations in microstrip technology such as narrow in bandwidth, low gain and normally contain spurious effect especially when dealing at frequency above $5 \mathrm{GHz}$ [1, 21-23].

Numerious improvement in terms of the antenna design using microstrip technology have been proposed. Amongst these, arrays concept is one of the popular technique. The base cell is used to construct the antenna design, arranged in an array manner; using different feeding techniques available today. The findings were reported that microstrip arrays antenna is possible to achieve high gain, acceptable desired radiation pattern with appropriate beamwidth [17, 23-25].

Based on this concept, three microstrip arrays patch antenna designs are proposed in this work. With arrangement of $4 \times 1,4 \times 2$ and $4 \times 3$ array patch antennas are proposed. The antennas are designed at $2.4 \mathrm{GHz}$ for WLAN applications. The performances of the antennas are investigated in terms of gain, return loss and compactness. To validate the concept, results are compared between simulations and measurements and are found agreeable. 


\section{RESEARCH METHOD}

The antennas proposed in this work are based on rectangular patch as shown in Figure 1, designed at 2.4 GHz for WLAN application. The specification of the antenna is as tabulated in Table 1. Quarter wavelength transformer is used to match the feeding line of the antennas.

Table 1. Specifications of Microstrip Patch Antenna Design of WLAN Application

\begin{tabular}{cc}
\hline Centre frequency, $\mathrm{f}_{0}$ & $2.4 \mathrm{GHz}$ \\
\hline Return Loss & $>10 \mathrm{~dB}$ \\
VSWR & 1 \\
Substrate specifications & Subtrate Thickness $=075 \mathrm{~mm}$, dielectric constant 3,3, loss tangent $=0.004$ \\
\hline
\end{tabular}

\subsection{Single Microstrip Patch Antenna Design}

Figure 1 illustrates the general view of single patch antenna with microstrip feedline. The design of the patch antenna consists of patch, quarter-wave transformer and feedline [16]. In (1-4) are applied to determine the dimensions of the single patch antenna in terms of width, $\mathrm{W}$ and length, $\mathrm{L}$ as follow [1]:
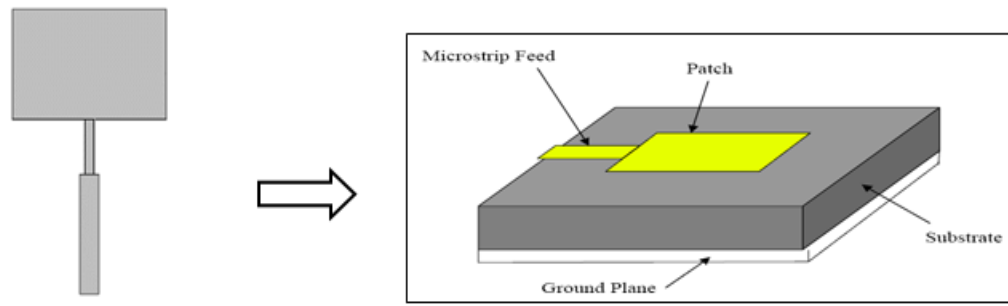

Figure 1. General view of rectangular patch antenna

Width of patch, wp is defined as follow:

$w_{p}=\frac{c}{2 f_{r}} \sqrt{\frac{2}{\varepsilon_{r}+1}}$

The effective dielectric constant is calculated by the formula below:

$\varepsilon_{r e f f}=\left(\frac{\varepsilon_{r}+1}{2}\right)+\left(\frac{\varepsilon_{r}-1}{2}\right)\left[1+12 \frac{h}{w}\right]^{-\frac{1}{2}}$

The genuine length of patch, $l_{p}$ is computed utilizing the accompanying formula:

$$
\begin{aligned}
& \frac{\Delta L}{t_{s}}=0.412 \frac{(\varepsilon f f+3)\left(\frac{w p}{t_{s}}+0.264\right)}{(\varepsilon f f-0.258)\left(\frac{w p}{t_{s}}+0.8\right)} \\
& l_{p}=\frac{C}{2 f_{o \sqrt{\varepsilon_{f f}}}}-2 \Delta L
\end{aligned}
$$

As stated in theory, the distance between the edge of patch and substrate must be more than $\frac{\lambda}{4}$ in order to avoid the signal to radiate more to ground. Thus, the length, $l_{s}$ and the width of substrate, $w_{s}$ are computed using these formulas:

$$
\begin{aligned}
& w_{s}=w_{p}+2\left(\frac{\lambda}{4}\right) \\
& l_{s}=l_{p}+2\left(\frac{\lambda}{4}\right)
\end{aligned}
$$


While the width of the quarter-wave line is obtained by $[2,10]$ :

$Z_{T}=\frac{60}{\sqrt{\varepsilon_{r}}} \ln \left(\frac{8 d}{w_{T}}+\frac{w_{r}}{4 d}\right)$

Where ZT is calculated as $[8,12]$ :

$Z_{T}=\sqrt{50+Z_{a}}$

The length of quarter line is calculated by:

$L_{T}=\frac{\lambda}{4}=\frac{\lambda_{o}}{4 \sqrt{\varepsilon_{e f f}}}$

And the width of the $50 \Omega$ microstrip feed is found using the well-known equation below:

$$
Z_{o}=\frac{120 \pi}{\sqrt{\varepsilon_{\text {reff }}\left(1.393+\frac{W}{h}+\frac{2}{3} \ln \left(\frac{W}{h}+1.444\right)\right)}}
$$

Using microstrip feeding technique, a simple rectangular microstrip patch antenna is designed with the layout as shown in Figure 2. This patch is used as base cell to construct the arrays.

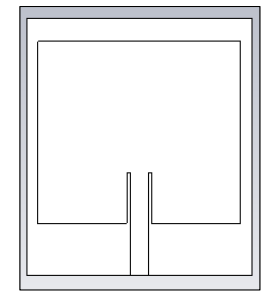

Figure 2. Single patch array design

\subsection{Microstrip Patch Array Antenna Design}

In designing array antenna, the base cells are arranged and feed using inset-fed technique as shown in Figure 3 while Table 2 tabulates all the calculated dimensions of the feedlines.

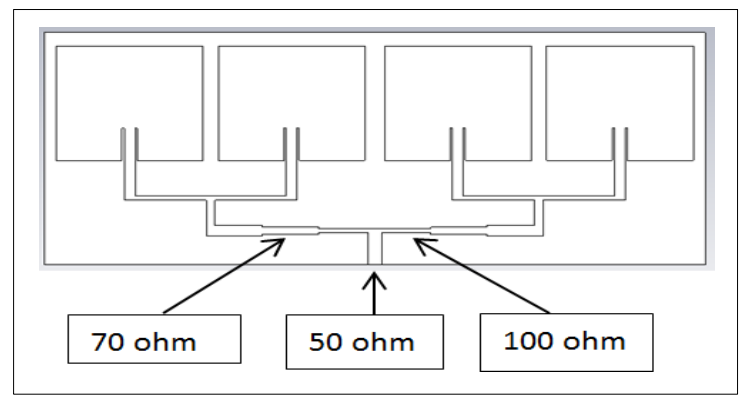

Figure 3. Patch array antenna with inset fed

Table.2. Dimension (Width and Length) of $100 \Omega, 70 \Omega$ and $50 \Omega$

\begin{tabular}{ccc}
\hline Impedance & Width $(\mathrm{mm})$ & Length $(\mathrm{mm})$ \\
\hline $50 \Omega$ & 3.3 & 9 \\
$70 \Omega$ & 13 & 2 \\
$100 \Omega$ & 13 & 1 \\
\hline
\end{tabular}


Figures 4, 5, and 6 illustrate the topologies of the 4x1 array, 4x2 array and 4x3 array patch antennas respectively, designed at $2.4 \mathrm{GHz}$. The antennas are simulated and the return losses, $\mathrm{S} 11$ of the antennas are shown in Figure 7. It can be seen that the performance of the $4 \times 3$ patch array antenna achieved the highest level of return loss which is $19.73 \mathrm{~dB}$.

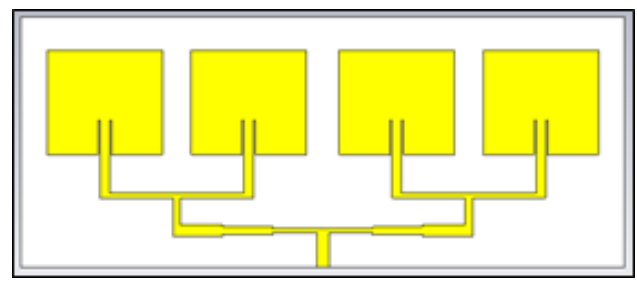

Figure 4. 4x1 patch array antenna design

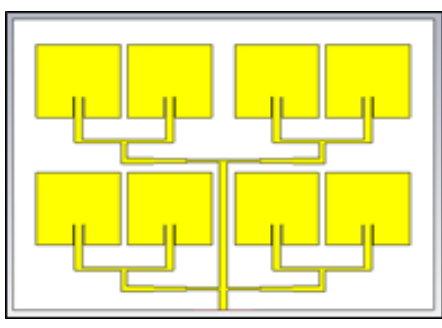

Figure 5. 4x2 patch array antenna design

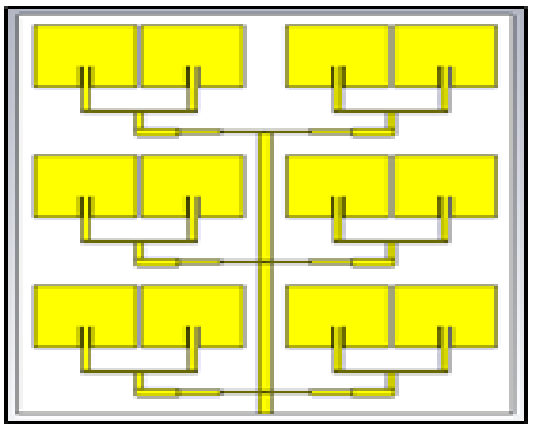

Figure 6. $4 \times 3$ patch array antenna design

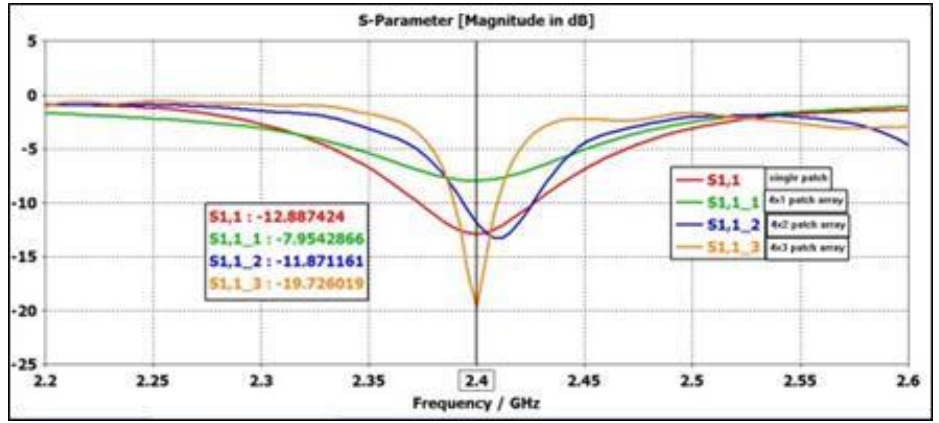

Figure 7. Comparison of return loss, S11

Table 3. Comparison of Simulation Results for All the Four Antenna Designs

\begin{tabular}{lcccc}
\hline & Single patch & $\begin{array}{c}4 \times 1 \text { patch array } \\
\text { antenna }\end{array}$ & $\begin{array}{c}4 \times 2 \text { patch array } \\
\text { antena }\end{array}$ & $\begin{array}{c}4 \times 3 \text { patch array } \\
\text { antenna }\end{array}$ \\
\hline Size of design $\left(\mathrm{cm}^{2}\right)$ & $45 \times 40=18$ & $157 \times 65=102.05$ & $170 \times 130=221$ & $275 \times 145=253.75$ \\
Return loss, $\mathrm{S}_{11}(\mathrm{~dB})$ & 12.89 & 7.95 & 11.87 & 19.73 \\
VSWR & 1.59 & 25.38 & 1.33 & 1.23 \\
Gain $(\mathrm{dB})$ & 4.25 & 7.31 & 8.49 & 11.41 \\
Directivity $(\mathrm{dBi})$ & 5.63 & 9.58 & 9.69 & 12.06 \\
\hline
\end{tabular}

Table 3 summarized the simulated the return loss and gain for all the designs obtained from CST simulation tool. It has shown that the $4 \times 3$ patch array antenna achieved highest gain compared to the other three antenna designs. Therefore, the $4 \times 3$ patch array transmits the highest power in the direction to that of an isotropic source. Based on these results, the $4 \times 3$ patch array antenna is chosen and the design is fabricated, analysed and compared with simulation results to validate the work. 


\section{RESULTS AND ANALYSIS}

Figure 8 illustrates the simulation results of Voltage Standing Wave Ratio (VSWR) and radiation pattern for the $4 \times 3$ array patch antenna, designed at $2.4 \mathrm{GHz}$. The VSWR achieved 1.23 and the radiation pattern shows directivity and gain of $10.39 \mathrm{~dB}$ and $9.08 \mathrm{~dB}$ respectively.

Figures 9 and 10 show the radiation pattern for simulated and measured respectively for the $4 \times 3$ patch array antenna. Both the radiation patterns portray the omnidirectional antenna that suit with WLAN applications. The simulation result in Figure 8(b), shows the major lobe directed the signal at $0^{\circ}$ with beamwidth (HPBW) of $43.3^{\circ}$. This antenna seems to generate more radiation power in the farfield region.

Figure 11(a) and (b) show the return loss and the prototype of the $4 \times 3$ array antenna. It is found that the measured return loss attenuated $19.85 \mathrm{~dB}$ at $2.427 \mathrm{GHz}$, shifted by $0.027 \mathrm{GHz}$ from the simulation. The shifted of measured result as compared to simulation may be due to some flaws during fabrication process and also may due to the effect of parasitic element on the substrate. [1]. Table 4 shows the comparison between the $4 \times 3$ patch array antenna with previous designs according to return loss and gain. In terms of return loss, the proposed antenna achieved highest gain compared to the other three designs.
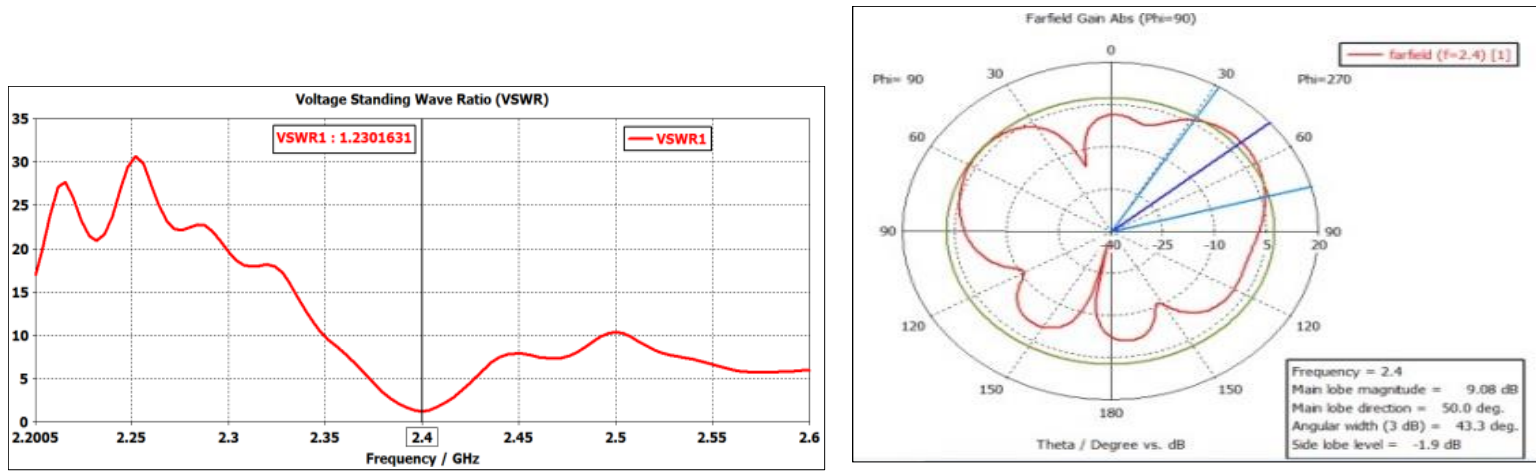

Figure 8. Simulation results of the $4 \times 3$ array patch antenna (a) VSWR, (b) radiation pattern

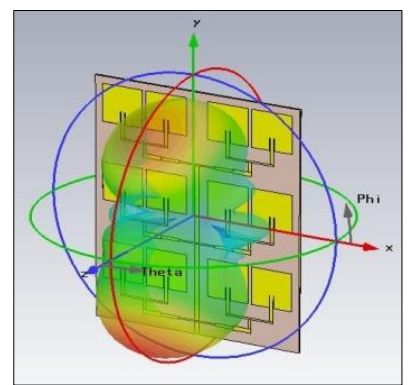

Figure 9. The 3-D radiation pattern of $4 \times 3$ array antenna

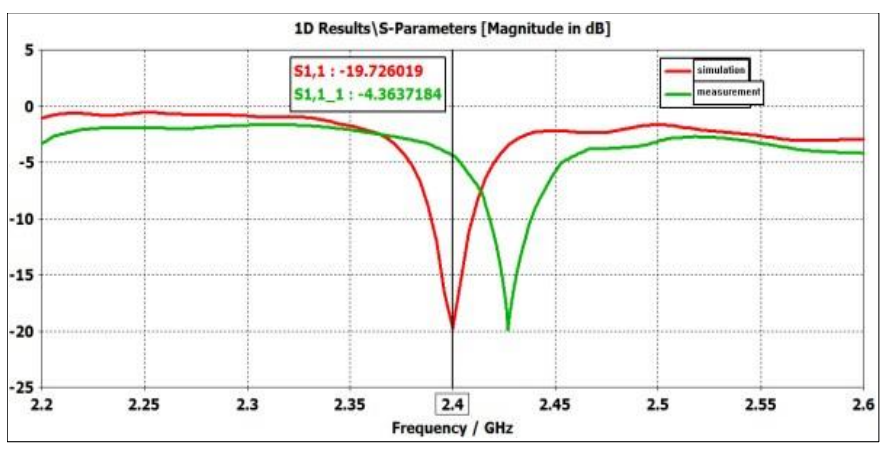

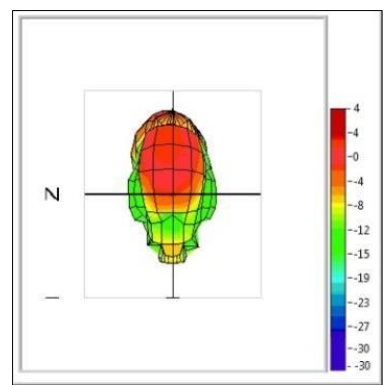

Figure 10. Measured radiation pattern (in 3-D front view) for $4 \times 3$ array patch antenna

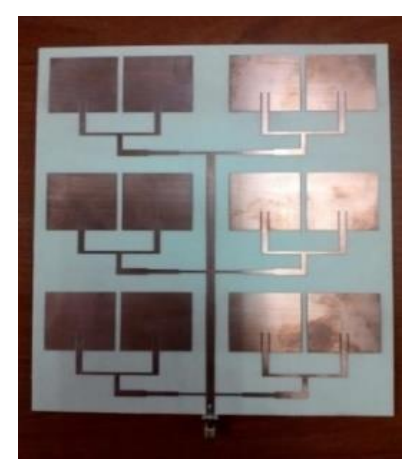

Figure 11. (a) S-Parameter: Return loss, S11 of the 4x3 array antenna, (b) Fabrication antenna 
Table 4. Comparison between this Work with Previous Designs

\begin{tabular}{ccc}
\hline Ref & S11 $(\mathrm{dB})$ & Gain \\
\hline $4 \times 1$ array [23] & 20.24 & 5.73 \\
$4 \times 2$ array [24] & 19.64 & 6.74 \\
$4 \times 3$ array:This work & 19.73 & 9.08 \\
\hline
\end{tabular}

\section{CONCLUSION}

Microstrip patch array antennas using microstrip feedline were presented. The antennas were simulated and compared in terms of gain and return loss. It was found that the $4 \times 3$ array antenna achieved best return loss and this antenna was fabricated. Results were compared between simulation and measurement and were found aggreable. Besides enriching the antenna bank, this antenna may be used for WLAN application.

\section{ACKNOWLEDGEMENT}

The authors would like to acknowledge The Institute of Quality and Knowledge Advancement (InQKA), Universiti Teknologi MARA (UiTM), Shah Alam, Selangor, Malaysia for the financial support of this manuscript.

\section{REFERENCES}

[1] A. Balanis, “Antenna Theory Analysis and Design, $3^{\text {rd }}$ Edition.” John Wiley \& Sons, 2005.

[2] V. Samarthay, S. Pundir and B. Lal, "Designing and Optimization of Inset Fed Rectangular Microstrip Patch Antenna (RMPA) for Varying Inset Gap and Inset Length" Int. J. Eng. Vol. 7, no. 9, pp. 1007-1013,2014

[3] B. Alisher and Z. Fazilbek, "Feed line calculations of microstrip antenna," Int. J. Res. Appl. Sci. Eng. Technol., vol. 4, no. 2321-9653, pp. 73-79, 2016.

[4] Taher Khalifa, N. M. Sahar, N. Ramli, M. T. Islam, "Circularly polarized microstrip patch antenna array for GPS application," Indonesian Journal of Electrical Engineering and Computer Science (IJEECS), Vol. 15, No. 2, August 2019, pp. 920-926.

[5] L. Xiong and P. Gao," Compact dual-band printed diversity antenna for WIMAX/WLAN applications, " Progress in Electromagnetics Research C, Vol. 32, 151-165, 2012.

[6] Adamu Y. Iliyasu, Mohamad Rijal Bin Hamid, Mohamad Kamal A. Rahim, Mohd Fairus Mohd Yusoff, "Wideband frequency reconfigurable metamaterial antenna employing SRR and CSRR for WLAN application," Indonesian Journal of Electrical Engineering and Computer Science, Vol. 15, No. 3, September 2019, pp. 1436-1442.

[7] X. Hou and H. Sun, "A Printed Monopole Antenna with Band Notches for WLAN / WiMAX Applications," pp. 400-402, 2014.

[8] B. Alisher and Z. Fazilbek, "Feed line calculations of microstrip antenna," Int. J. Res. Appl. Sci. Eng. Technol., vol. 4, no. 2321-9653, pp. 73-79, 2016.

[9] Azman, M. Z. A. A. Aziz, M. K. Suaidi, and H. Nornikman, "Design 2x2 Patch Array with L Slot Antenna for WiMAX and WLAN", pp. 455-458, 2015.

[10] R. Karthik, "Double L - Slot Microstrip Patch Antenna Array for WiMAX and WLAN," pp. 137-140, 2012

[11] P. Subbulakshmi, "Rectangular Microstrip Patch Array Antenna," Emerging Trends in Computing, Communication and Nanotechnology Conference (ICECCN) IEEE, pp. 547-552, 2013.

[12] Shashi Kumar and S. Suganthi,"Performance Analysis of Optimized Corporate-Fed Microstrip Array for ISM Band Applications," IEEE WiSPNET 2017.

[13] Singh, M. Aneesh, Kamakshi, and J. A. Ansari, "Analysis of Microstrip Line Fed Patch Antenna for Wireless Communications,” Open Eng., vol. 7, no. 1, pp. 279-286, 2017.

[14] Abil Fathir Majid, Yulisdin Mukhlis, "Aperture coupling rectangular slotted circular ring microstrip patch antenna," Indonesian Journal of Electrical Engineering and Computer Science (IJEECS), Vol. 15, No. 3, September 2019, pp. 1419-1427

[15] Shashi Kumar and S. Suganthi,"Performance Analysis of Optimized Corporate-fed Microstrip Array for ISM Band Applications," IEEE WiSPNET 2017.

[16] Arora, A. Khemchandani, Y. Rawat, S. Singhai, and G. Chaitanya, "Comparative study of different feeding techniques for rectangular microstrip patch antenna," Int. J. Innov. Res. Electr. Electron. Instrum. Control Eng., vol. 3, no. 5, pp. 32-35, 2015

[17] Manotosh Biswas, and Mausumi Sen, "Design and Development of Coax-Fed Electromagnetically Coupled Stacked Rectangular Patch Antenna for Broad Band Application," Progress in Electromagnetics Research B, vol. 79, pp. 21-44, 2017.

[18] Verma, O. P. Singh, and G. R. Mishra, “Analysis of feeding mechanism in microstrip patch antenna," Int. J. Res. Eng. Technol., vol. 3, no. 4, pp. 786-792, 2014.

[19] V. Samarthay, S. Pundir and B. Lal, "Designing and Optimization of Inset Fed Rectangular Microstrip Patch Antenna (RMPA) for Varying Inset Gap and Inset Length” Int. J. Eng. Vol. 7, no. 9, pp. 1007-1013,2014. 
[20] B. Alisher and Z. Fazilbek, "Feed line calculations of microstrip antenna," Int. J. Res. Appl. Sci. Eng. Technol., vol. 4, no. 2321-9653, pp. 73-79, 2016.

[21] P. Jain, K. S. Yadav, D. K. Bhagat, P. Banwani, and P. Amity, "Design of rectangular microstrip patch antenna with circular and rectangular slot in X Band," pp. 162-168.

[22] Singh, M. Aneesh, Kamakshi, and J. A. Ansari, "Analysis of microstrip line fed patch antenna for wireless communications," Open Eng., vol. 7, no. 1, pp. 279-286, 2017.

[23] Manotosh Biswas, Mausumi Sen, "Design and Development of Coax-Fed Electromagnetically Coupled Stacked Rectangular Patch Antenna for Broad Band Application," Progress in Electromagnetics Research B, vol. 79, pp. 21-44, 2017.

[24] N. A. Wahab, Z. Maslan, W. N. W. Muhamad, and N. Hamzah, "Microstrip Rectangular 4x1 Patch Array Antenna at 2.5GHz for WiMax Application," CICSyN 2010, Liverpool, UK, 28-30 July, pp. 2-6, 2010.

[25] Amitha R. Nair, B. A. Singh, and S. S. Thakur, "Design of Rectangular Microstrip4x2 Patch Array Antenna at 2.4 GHz for WLAN Application," IEEE International Conference on Advances in Computing and Communication, no. 2, pp. 2-5, 2015.

\section{BIOGRAPHIES OF AUTHORS}
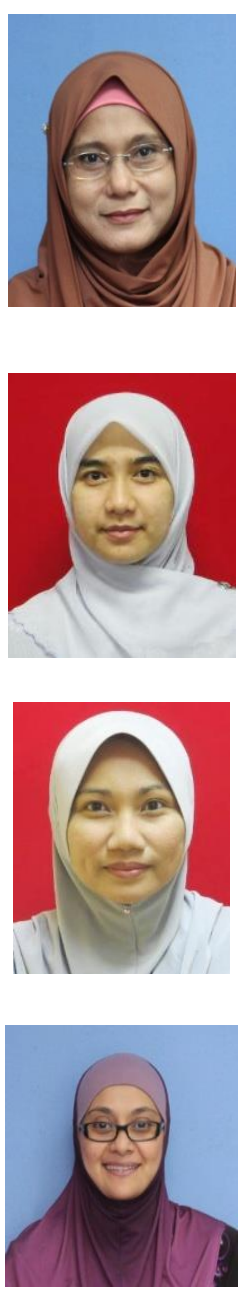

Norfishah Ab Wahab was born in Malaysia, in 1963. She received the degree in Electronics Engineering from Universiti Teknologi MARA (UiTM), Malaysia, MSc in Telecommunication and Information Engineering and $\mathrm{PhD}$ in microwaves, electromagnetism in the same university. Currently, she is a senior lecturer in Faculty of Electrical Engineering, UiTM Shah Alam, Malaysia. She has been working in UiTM since April 2008. From 1992 to 2004, she was employed by Telekom Malaysia. She worked in various divisions such as microwave, fiber cable and network system departments. Her major research areas are in microwave and electromagnetic modeling, low-powered electronic design, energy harvesting and efficiency.

Wan Norsyafizan W. Muhamad was born in Malaysia, in 1978. She received the degree in Electrical Engineering and Master of Electrical Engineering from Universiti Malaya Malaysia and $\mathrm{PhD}$ in Computer Engineering from University of Newcastle, Australia in 2017. She is now a senior lecturer in Faculty of Electrical Engineering, UiTM Shah Alam, Malaysia. Her major research area is in Wireless Communication (Physical and MAC cross layer optimization).

Suzi Seroja Sarnin was born on January $28^{\text {th }}$, 1974 in Selangor, Malaysia. She received her Bachelor of Electrical and Electronics (B.Eng), in field of Communication from the Universiti Teknologi Malaysia, Skudai, Malaysia in 1999. She completed her Master of Microelectronics (Msc), from the Universiti Kebangsaan Malaysia in 2005 and obtained her PhD in Electrical Engineering from Universiti Teknologi MARA, Shah Alam, Selangor, Malaysia. She is now a senior lecturer in Faculty of Electrical Engineering, UiTM Shah Alam, Selangor, Malaysia.

Zuhani Ismail Khan received her Bachelor of Engineering in Electrical and Electronic Engineering from University of Bradford, United Kingdom and MSc in Computer and Information Engineering from International Islamic University Malaysia, Gombak in 1998 and 2008 respectively. She received her PhD in Electrical Engineering from Universiti Teknologi MARA (UiTM) Shah Alam in 2015. Currently being appointed as the Head of Department for Communication Engineering with a vison to uphold the department and faculty as an active research hub in RF and Microwave devices and systems, and Wireless Communication Technologies. 